Киричко Б. П., доктор ветеринарних наук, професор, Звенігородська T. В., аспірант

(науковий керівник - доктор ветеринарних наук, професор Б. П. Киричко)

Полтавська державна аграрна академія

\title{
БІОХІМІЧНІ ПОКАЗНИКИ КРОВІ ТА РОТОВОЇ РІДИНИ ЗА ЛІКУВАННЯ ХРОНІЧНОГО ГЕНЕРАЛІЗОВАНОГО ПАРОДОНТИТУ У СВІЙСЬКИХ КОТІВ
}

\section{Рецензент -доктор ветеринарних наук, професор С. М. Кулинич}

Встановлено, щзо за хронічного генералізованого пародонтиту у свійських котів відбувається підвищення вмісту загального білка $(P<0,001), \gamma$-глобулінів $(P<0,001)$, глюкози $(P<0,001)$ у сироватиі крові та загального білка $(P<0,001) i$ глюкози $(P<0,001)$ у ротовій рідині у порівнянні з клінічно здоровими котами. Поєднання консервативного й оперативного методів лікування хронічного генералізованого пародонтиту в котів трьох дослідних груп дає позитивний ефект і сприяє зниженню вмісту загального біл$\kappa$, глюкози та $\gamma$-глобулінів. Проте найліпші результати отримані у тварин четвертої дослідної групи, яким у комплексі лікувальних заходів застосовували остеотропний препарат «Коллапан».

Ключові слова: свійські коти, пародонтит, лікування.

Постановка проблеми. Ветеринарна стоматологія дрібних свійських тварин - новий і актуальний розділ у клінічній ветеринарній хірургії. У клінічній практиці все більше з'являється тварин із захворюваннями, що локалізуються в ротовій порожнині. На сьогоднішній день у вітчизняній ветеринарній медицині хвороби пародонту 3 урахуванням причин їх виникнення, клінічних форм прояву та перебігу недостатньо систематизовані, уривчасті, не достатньо описані, що не дає цілковитого уявлення про існуючу проблему $[2,5]$.

Аналіз основних досліджень і публікацій, у яких започатковано розв'язання проблеми. Пародонтопатії реєструються переважно у тварин дорослого віку. Причини різноманітні - як місцеві, так і загальні. Генетична схильність, особливості породи та екстер'єру, порушення розвитку кістяка призводять до формування неправильного прикусу й некомплектних зубів. Це, в свою чергу, сприяє накопиченню нашарувань $\mathrm{i}$ зубного каменя, що є одним із найважливіших патогенних чинників у розвитку пародонтопатій. Значну роль у розвитку запальних хвороб пародонту відіграє обмін речовин. Пародонт кісткова тканина щелеп на 80 \% складаються 3 колагену, тому за деструктивних процесах важливим критерієм $\epsilon$ вміст білка в сироватці та ротовій рідині $[1,3,4]$.

Мета роботи: дослідити зміни біохімічного складу сироватки крові та ротової рідини у котів за лікування пародонтиту різними методами.

Завдання: проаналізувати зміни біохімічного складу сироватки крові та ротової рідини за пародонтиту та в процесі лікування.

Матеріали і методи. Матеріалом дослідження були зразки крові та ротової рідини, відібрані в котів, у яких реєстрували хронічних генералізований пародонтит. Їх відбирали до початку лікування, на 5-ту, 15-ту та 45-ту добу від початку лікування. Для порівняння було відібрано зразки від клінічно здорових тварин $(\mathrm{n}=6)$. Зразки крові отримували шляхом пункції зовнішньої яремної вени, а ротову рідину - аспірацією останньої $з$ ротової порожнини після застосування подразника. Дотримувалися існуючих правил асептики й антисептики. Вміст загального білка визначали за біуретовою реакцією, рівень глюкози ротової рідини та сироватки крові визначали глюкозооксидантним методом. Білкові фракції досліджувалися нефелометричном методом [3].

Лікування призначали 3 урахуванням ступеня тяжкості патологічного процесу й індивідуальних особливостей організму. Для того, щоб визначити ефективність різних лікувальних схем, хворих тварин поділили на чотири групи. Перша група $(\mathrm{n}=6)$ - коти 3 легким і середнім ступенем пародонтиту, яким проводили лише професійну чистку та полірування зубів, промивання пародонтальних кишень фізрозчином; друга група $(\mathrm{n}=6)$ - коти 3 легким та середнім ступенем тяжкості пародонтиту, яким після професійного чищення зубів проводили протизапальну терапію у вигляді $0,01 \%$ розчину мірамістину; третя група $(\mathrm{n}=6)$ - коти 3 легким, середнім і тяжким ступенем пародонтиту, яким проводили кюретаж та клаптеві операції з наступним використанням стоматологічного геля «Зубастик»; четверта група $(\mathrm{n}=6)$ - коти, яким після проведеної клаптевої операції в кісткову кишеню вводили 
ВЕТЕРИНАРНА МЕДИЦИНА

\section{1. Динаміка біохімічних показників сироватки крові котів за лікування хронічного генералізованого пародонтиту, $M \pm m, n=6$}

\begin{tabular}{|c|c|c|c|c|c|c|}
\hline \multirow{2}{*}{\multicolumn{2}{|c|}{$\begin{array}{c}\text { Період дослідження та групи } \\
\text { тварин }\end{array}$}} & \multirow{2}{*}{$\begin{array}{l}\text { Загальний } \\
\text { білок, г/л }\end{array}$} & \multirow{2}{*}{$\begin{array}{l}\text { Альбу- } \\
\text { міни, \% }\end{array}$} & \multicolumn{2}{|c|}{ Глобуліни, \% } & \multirow{2}{*}{$\begin{array}{c}\text { Глюкоза, } \\
\text { ммоль/л }\end{array}$} \\
\hline & & & & $\alpha 1,2$ & $\gamma$ & \\
\hline Клінічно здс & ові $(n=6)$ & $55,4 \pm 4,11$ & $42,4 \pm 2,6$ & $10 \pm 1,6$ & $12,3 \pm 1,52$ & $4,7 \pm 0,03$ \\
\hline \multirow{4}{*}{$\begin{array}{l}\text { До початку } \\
\text { лікування }\end{array}$} & $\begin{array}{l}\text { перша група } \\
(\mathrm{n}=6)\end{array}$ & $75,6 \pm 1,4 \bullet \bullet \bullet$ & $45,2 \pm 1,3$ & $8,8 \pm 0,4$ & $49,4 \pm 3,1 \cdots$ & $8,6 \pm 0,2 \bullet \bullet$ \\
\hline & $\begin{array}{l}\text { друга група } \\
(\mathrm{n}=6)\end{array}$ & $76,2 \pm 1,2 \bullet \bullet$ & $47,6 \pm 1,7$ & $9,4 \pm 0,52$ & $50,6 \pm 2,5 \bullet \bullet$ & $8,2 \pm 0,34 \cdots \bullet$ \\
\hline & $\begin{array}{l}\text { третя група } \\
(\mathrm{n}=6)\end{array}$ & $80,2 \pm 2,2 \bullet \bullet$ & $47,8 \pm 1,4$ & $9,8 \pm 0,64$ & $49,8 \pm 1,8 \cdots \bullet$ & $8,8 \pm 0,5 \bullet \bullet$ \\
\hline & $\begin{array}{l}\text { четверта гру- } \\
\text { па }(\mathrm{n}=6)\end{array}$ & $79,8 \pm 1,8 \bullet \bullet \bullet$ & $48,1 \pm 2,4$ & $9,5 \pm 0,5$ & $50,8 \pm 2,3 \bullet \bullet \bullet$ & $8,6 \pm 0,3 \bullet \bullet$ \\
\hline \multirow{4}{*}{$\begin{array}{l}\text { На 5-ту } \\
\text { добу }\end{array}$} & $\begin{array}{l}\text { перша група } \\
(\mathrm{n}=6)\end{array}$ & $72,8 \pm 2,2$ & $44,2 \pm 1,8$ & $9,4 \pm 0,5$ & $36,2 \pm 3,3^{*}$ & $8,4 \pm 0,5$ \\
\hline & $\begin{array}{l}\text { друга група } \\
(\mathrm{n}=6)\end{array}$ & $73,4 \pm 1,9$ & $45,8 \pm 1,6$ & $9,2 \pm 0,3$ & $39,4 \pm 1,8^{* *}$ & $7,4 \pm 0,4$ \\
\hline & $\begin{array}{l}\text { третя група } \\
(\mathrm{n}=6)\end{array}$ & $68,4 \pm 1,1 * * *$ & $46,6 \pm 1,8$ & $10,1 \pm 0,4$ & $37 \pm 2,2 * * *$ & $7,2 \pm 0,5^{*}$ \\
\hline & $\begin{array}{l}\text { четверта гру- } \\
\text { па }(\mathrm{n}=6)\end{array}$ & $66,42 \pm 1,5^{* * *}$ & $44,9 \pm 1,3$ & $9,2 \pm 1,04$ & $39,8 \pm 2,6^{*}$ & $7,4 \pm 0,6$ \\
\hline \multirow{4}{*}{$\begin{array}{l}\text { На } 15 \text {-ту } \\
\text { добу }\end{array}$} & $\begin{array}{l}\text { перша група } \\
(\mathrm{n}=6)\end{array}$ & $70,3 \pm 1,7^{*}$ & $43,3 \pm 1,44$ & $9,2 \pm 0,5$ & $40,2 \pm 2,44 *$ & $7,9 \pm 0,14^{*}$ \\
\hline & $\begin{array}{l}\text { друга група } \\
(\mathrm{n}=6)\end{array}$ & $68,7 \pm 1,7^{* *}$ & $43,8 \pm 1,2$ & $9,12 \pm 0,8$ & $28,5 \pm 0,94 * * *$ & $6,2 \pm 0,23 * * *$ \\
\hline & $\begin{array}{l}\text { третя група } \\
(\mathrm{n}=6)\end{array}$ & $64,8 \pm 0,91 * * *$ & $43,6 \pm 0,94$ & $10,2 \pm 1,2$ & $25,9 \pm 2,8 * * *$ & $5,8 \pm 0,9^{*}$ \\
\hline & $\begin{array}{l}\text { четверта гру- } \\
\text { па }(\mathrm{n}=6)\end{array}$ & $62,2 \pm 1,2 * * *$ & $42,1 \pm 0,8$ & $9,8 \pm 0,74$ & $26,2 \pm 2,4 * * *$ & $6,0 \pm 0,3 * * *$ \\
\hline \multirow{4}{*}{$\begin{array}{l}\text { На 45-ту } \\
\text { добу }\end{array}$} & $\begin{array}{l}\text { перша група } \\
(\mathrm{n}=6)\end{array}$ & $70,4 \pm 2,1$ & $44,6 \pm 1,33$ & $9,2 \pm 0,4$ & $42,6 \pm 1,5$ & $7,2 \pm 1,2$ \\
\hline & $\begin{array}{l}\text { друга група } \\
(\mathrm{n}=6)\end{array}$ & $69,2 \pm 0,92 * *$ & $43,8 \pm 1,2$ & $9,6 \pm 0,4$ & $22,4 \pm 1,8 * * *$ & $5,4 \pm 0,8 * *$ \\
\hline & $\begin{array}{l}\text { третя група } \\
(\mathrm{n}=6)\end{array}$ & $62,8 \pm 1,5^{* * *}$ & $42,2 \pm 1,12$ & $9,8 \pm 1,2$ & $16,6 \pm 0,9 * * *$ & $5,9 \pm 0,5^{* * *}$ \\
\hline & $\begin{array}{l}\text { четверта гру- } \\
\text { па }(\mathrm{n}=6)\end{array}$ & $62,4 \pm 1,7 * * *$ & $42,8 \pm 1,6$ & $9,6 \pm 0,52$ & $17,2 \pm 0,6 * * *$ & $5,82 \pm 0,5 * * *$ \\
\hline
\end{tabular}

Примітки: $1 .{ }^{*}-\mathrm{P}<0,05, * *-\mathrm{P}<0,01, * * *-\mathrm{P}<0,001$ порівняно 3 показниками до лікування 2. $-\mathrm{P}<0,05, \bullet-\mathrm{P}<0,01, \cdots-\mathrm{P}<0,001$ порівняно з клінічно здоровими тваринами

остеопластичний препарат «Коллапан» із наступним використанням стоматологічного геля «Зубастик».

Результати досліджень. Динаміка окремих біохімічних показників сироватки крові котів за лікування хронічного генералізованого пародонтиту наведена в таблиці 1 . Досліджуючи сироватку крові котів, хворих на пародонтит, відмічали підвищення вмісту загального білка $(\mathrm{P}<0,001), \quad \gamma$-глобулінів $(\mathrm{P}<0,001), \quad$ глюкози $(\mathrm{P}<0,001)$ по відношенню до клінічно здорових котів.

Підвищений вміст $\gamma$-глобулінів свідчить про існування в організмі інфекцій або запалень $[3,4]$.

На 5-ту добу лікування в третій та четвертій дослідних групах тварин спостерігали вірогідне зниження вмісту загального білка та $\gamma$-глобулінів, що свідчить про зменшення інтенсивності запалення й руйнування тканин. На 15-у добу в усіх групах відмічали зниження вмісту загального білка: в першій групі - на $3,7 \%(\mathrm{P}<0,05)$, у другій - на $19,8 \%(\mathrm{P}<0,01)$, у третій - на $14,7 \% \quad(\mathrm{P}<0,001)$, у четвертій - на $20,1 \%$ $(\mathrm{P}<0,001) ; \gamma$-глобулінів у першій групі - на $18,6 \%(\mathrm{P}<0,05)$, у другій - на 43,7 \% (P<0,001), 
ВЕТЕРИНАРНА МЕДИЦИНА

\section{2. Динаміка біохімічних показників ротової рідини котів за лікування хронічного генералізованого} пародонтиту, $M \pm m, n=6$

\begin{tabular}{|c|c|c|c|}
\hline \multicolumn{2}{|c|}{ Період дослідження та групи тварин } & Загальний білок, г/л & Глюкоза, ммоль/л \\
\hline \multicolumn{2}{|c|}{ Клінічно здорові тварини (n=6) } & $11,3 \pm 0,51$ & $1,02 \pm 0,4$ \\
\hline \multirow{4}{*}{$\begin{array}{l}\text { До початку } \\
\text { лікування }\end{array}$} & перша група (n=6) & $19,6 \pm 0,4 \bullet \bullet \bullet$ & $3,4 \pm 0,4 \bullet \bullet$ \\
\hline & друга група (n=6) & $19,9 \pm 0,4 \cdots \bullet$ & $3,5 \pm 0,22 \bullet \bullet$ \\
\hline & третя група (n=6) & $19,2 \pm 0,5 \bullet \bullet$ & $3,2 \pm 0,32 \bullet \bullet$ \\
\hline & четверта група (n=6) & $20 \pm 0,61 \bullet \bullet$ & $3,6 \pm 0,3 \bullet \bullet \bullet$ \\
\hline \multirow{4}{*}{ На 5-ту добу } & перша група (n=6) & $17,4 \pm 0,5 * *$ & $2,7 \pm 0,4$ \\
\hline & друга група (n=6) & $14,3 \pm 0,3 * * *$ & $2,4 \pm 0,02 * * *$ \\
\hline & третя група (n=6) & $13,2 \pm 0,6^{* * *}$ & $2,2 \pm 0,04^{*}$ \\
\hline & четверта група (n=6) & $12,8 \pm 0,41 * * *$ & $2,2 \pm 0,02 * *$ \\
\hline \multirow{4}{*}{ На 15-ту добу } & перша група (n=6) & $16,2 \pm 1,2 *$ & $2,5 \pm 0,4$ \\
\hline & друга група (n=6) & $12,6 \pm 0,5^{* * *}$ & $1,8 \pm 0,1 * * *$ \\
\hline & третя група (n=6) & $12,4 \pm 0,2 * * *$ & $1,4 \pm 0,04 * * *$ \\
\hline & четверта група $(\mathrm{n}=6)$ & $11,8 \pm 0,7 * * *$ & $1,4 \pm 0,03 * * *$ \\
\hline \multirow{4}{*}{ На 45-ту добу } & перша група (n=6) & $16,6 \pm 1,4$ & $2,62 \pm 0,04$ \\
\hline & друга група (n=6) & $12,5 \pm 0,33 * * *$ & $1,5 \pm 0,04 * * *$ \\
\hline & третя група (n=6) & $11,8 \pm 0,6^{* * *}$ & $1,4 \pm 0,1 * * *$ \\
\hline & четверта група (n=6) & $11,2 \pm 0,4 * * *$ & $1,34 \pm 0,03 * * *$ \\
\hline
\end{tabular}

Примітки: $1 .{ }^{*}-\mathrm{P}<0,05, * *-\mathrm{P}<0,01, * * *-\mathrm{P}<0,001$ порівняно $з$ показниками до лікування 2. • $-\mathrm{P}<0,05, \cdot \bullet-\mathrm{P}<0,01, \cdot \cdots-\mathrm{P}<0,001$ порівняно з клінічно здоровими тваринами

у третій - на $48 \%(\mathrm{P}<0,001)$, у четвертій - на $48,4 \%(\mathrm{P}<0,001)$; глюкози у першій групі - на $8,2 \% \quad(\mathrm{P}<0,05)$, у другій групі - на $24,4 \%$ $(\mathrm{P}<0,001)$, у третій групі - на $34,1 \%(\mathrm{P}<0,05)$, у четвертій групі - на $30,2 \%(\mathrm{P}<0,001)$.

Віддалені дослідження на 45-ту добу показали, що показники тварин першої (контрольної) групи залишаються дещо зниженими, проте невірогідно.

У другій, третій та четвертій дослідних групах показники загального білка, $\gamma$-глобулінів та глюкози статистично вірогідно зменшилися, хоча залишалися вищими, ніж у групі тварин з інтактним пародонтом.

Зміни біохімічних показників ротової рідини котів за лікування хронічного генералізованого пародонтиту наведені в таблиці 2.

У ротовій рідині хворих котів також відмічали збільшення вмісту загального білка $(\mathrm{P}<0,001)$ та глюкози $(\mathrm{P}<0,01)$ по відношенню до котів з інтактним пародонтом.

Підвищення концентрації білка в ротовій рідині може відігравати захисну роль. Він зв'язує токсичні продукти життєдіяльності мікрофлори, a також ендогенного клітинного походження, мінеральні речовини для підтримки обмінних процесів у тканинах і органах порожнини рота.

Разом із тим, депонування у складі білкових макромолекул токсинів може служити фактором вторинного пошкодження тканин пародонту, алергізації організму, розвитку аутоімунних порушень [2]. 


\section{ВЕТЕРИНАРНА МЕДИЦИНА}

У першій групі котів на 5-ту та 15-ту добу лікування відбувається зменшення в ротовій рідині вмісту загального білка на 17,35 \% $(\mathrm{P}<0,01)$, коливання рівня глюкози невірогідні.

В другій, третій та четвертій дослідних групах iз 5-ї по 45-ту добу реєстрували вірогідне зниження вмісту загального білка та глюкози $(\mathrm{P}<0,001)$.

На 45-ту добу в другій групі вміст загального білка становить $12,5 \pm 0,33$ г/л, у третій групі $11,8 \pm 0,6$ г/л, у четвертій $-11,2 \pm 0,4$ г/л.

Вміст глюкози знижується до 1,5 $\pm 0,04$ ммоль/л - у другій групі, до 1,4 $\pm 0,1$ ммоль/л - у третій групі та до 1,34 $\pm 0,03$ ммоль/л - у четвертій групі.

\section{БІБЛІОГРАФІЯ}

1. Васильева М. Б. Воспалительные заболевания пародонта у собак: дис.... канд. вет. наук: 16.00 .05 «Ветеринарная хирургия» / Майя Борисовна Васильева. - СПб, 2009. - С. 71-101.

2. Карпович E. A. Клинико-рентгенографическая диагностика и оперативное лечение пульпита коренных зубов у собак: авт. дис.... канд. вет. наук: спец. 16.00.05 «Ветеринарная хирургия» / Е. А. Карпович. - М., 2010. - 18 с.

3. Методы клинической ветеринарной лабораторной диагностики / [И. П. Кондрахин,
Висновки:

1. У котів, хворих на хронічний генералізований пародонтит, відмічається підвищення загального білка $(\mathrm{P}<0,001), \gamma$-глобулінів $(\mathrm{P}<0,001)$, глюкози $(\mathrm{P}<0,001)$ у сироватці крові та загального білка $(\mathrm{P}<0,001)$ і глюкози $(\mathrm{P}<0,001)$ в ротовій рідині порівняно з клінічно здоровими котами.

2. У період лікування в усіх дослідних групах відмічали статистично вірогідне зменшення загального білка, глюкози та $\gamma$-глобулінів, що може свідчити про затухання запальної реакції. Найкращі результати отримані у тварин четвертої дослідної групи, яким у комплексі лікувальних заходів, застосовували остеотропний препарат «Коллапан».

А. В. Архипов, И. В. Левченко и др.] / Под ред. И. П. Кондрахина. - М. : Колос, 2004. - 520 с.

4. Орехова Л. Ю. Заболевания пародонта / Л. Ю. Орехова. - М. : Полимедиапресс, 2004. C. $107-140$.

5. Сарбаш Д. В. Етіологія, класифікація і клінічні прояви захворювань зубощелепового апарату у тварин / Д. В. Сарбаш, Д. В. Слюсаренко, К. А. Синяговська // Ветеринарна медицина України. - 2011. - № 9. - С. 40-43. 